\title{
BRCC3 Gene
}

National Cancer Institute

\section{Source}

National Cancer Institute. BRCC3 Gene. NCI Thesaurus. Code C124109.

This gene plays a role in the deubiquitination of histones. 